Egyptian Journal of Rabbit Science, 25(1): 119 - 136(2015)

\title{
EFFECT OF SOME BEE PRODUCTS ON REPRODUCTIVE PHENOMENA OF MALE NEW ZEALAND WHITE RABBITS
}

\section{A.M. El-Sherbiny}

Animal Prod. Dept., Faculty Agric., Ain Shams University, Cairo, Egypt.

The present work was designed to study the effect of propolis $(P)$ with or without royal jelly $(R J)$ and bee honey $(H)$ on age of sexual puberty, semen quality and fertility of New Zealand White (NZW) rabbit males. Sixty pre-pubertal NZW rabbit males were used in the present study and were randomly divided into 3 groups (20 bucks per group); males were administered orally with $0.5 \mathrm{~mL}$ of a solution/ $\mathrm{kg}$ body weight $(\mathrm{BW}), 3$ times weekly for 6 weeks. The solution contained: 1) water for control ( $1^{\text {st }}$ group), 2) $15 \mathrm{mg}$ propolis with $200 \mathrm{mg}$ royal jelly $(R J)$ suspended in $0.25 \mathrm{~mL}$ bee honey $(H)+0.25 \mathrm{~mL}$ water $\left(2^{\text {nd }}\right.$ group $)$, 3) $15 \mathrm{mg}$ propolis $(P)$ was suspended in $0.5 \mathrm{~mL}$ water ( $3^{\text {rd }}$ group). Fertility of rabbit bucks was tested using artificial insemination of 60 hybrid nonparous rabbit females (20 females per each experimental group).

Male NZW rabbits received propolis with or without royal jelly and bee honey showed significant $(P<0.05)$ earlier age at puberty (earlier ages at testis descending into scrotum, separation of penis from sheath, fighting, first ejaculation, appearance of sperm in testis and epididymis). The results also revealed significant $\left(P<0.0^{\circ}\right)$ increase of ejaculate volume, percentage of sperm progressive motility, sperm-cell concentration and seminal plasma fructose concentration in treated groups compared to control group. On the other hand, reaction time, percentages of dead and abnormal spermatozoa increased significantly $\left(P<0.0^{\circ}\right)$ for control group compared to the other two groups. Blood plasma concentration of testosterone increased significantly $\left(P<0.0^{\circ}\right)$ for both $2^{\text {nd }}$ and $3^{\text {rd }}$ groups in comparison with control. Otherwise, plasma concentrations of cholesterol, aspartate amino transferase (AST) and alanine amino transferase (ALT) were reduced 
significantly $\left(P<0.0^{\circ}\right)$ for $2^{\text {nd }}$ and $3^{\text {rd }}$ groups compared to control group. Rabbit bucks treated with either propolis with or without royal jelly and bee honey showed better fertility (higher conception rate and litter size) than control bucks.

In conclusion, the results of the present study showed that oral administration of NZW rabbit males with propolis only or with royal jelly and bee honey could be used beneficially to have earlier age of puberty, improve semen quality and fertility. This improvement was also mirrored on better liver functions.

Keywords: Fertility, propolis, puberty, rabbits, semen.

Rabbits are considered one of the important livestock that provide high quality protein, rabbit also represents an ideal laboratory animal in the field of reproduction. It is easy to handle due to its size (Naughton et al., 2003).

Developing and maintaining the reproductive efficiency in rabbits is important to the economy of the rabbit industry. Age at sexual puberty is one of the most important parameters affecting the reproductive efficiency of farm animals. The age at puberty is influenced by environmental temperature, photoperiod, age and breed of animal, heterosis, body weight (as affected by nutrition), and growth rate before and after weaning (Hafez and Hafez, 2000).

Propolis has been known as natural resinous substance collected by bees from parts of plants, buds and exudates (Zhou et al., 2008). Propolis has several therapeutic properties including antioxidant, antimicrobial, antiparasitic, antiviral, anti-inflammatory and antitumoral properties (Kumazawa et al., 2004; Paulino et al., 2008). Moreover, inclusion of propolis in male rabbit's diets during the hot season could be used effectively to mitigate negative impacts of elevated temperature on semen quality of NZW rabbit bucks (Hashim et al., 2013).

Royal jelly (RJ) is a secretion product of the cephalic glands of nurse bees that has been used for centuries for its extraordinary properties and health effects (Mărghitas, 2008; Pavel et al., 2011). Royal jelly, a unique natural created food that helps to balance the body 
nutritionally and enhance reproductive characteristics of female rabbits (Khattab et al., 1989) and reproductive performance of sheep (Husein and Haddad, 2006). On rabbits, Elnagar (2010) concluded that RJ administration to heat stressed male rabbits can counteract their "summer infertility" and improve their physiological status and also for growing rabbits (Elnagar et al., 2010). Hassan (2009) found that, royal jelly is a beneficial treatment of male rats especially on sperm count and livability. Further experimentation (in vitro, in animal's research) and validation would be needed to prove any useful benefit and action mechanism of native propolis, bee honey and RJ and isolated compounds as well.

Therefore, this study was designed to evaluate the effects of propolis with /or without royal jelly and bee honey on age at puberty, semen characteristics and fertility of male NZW rabbits.

\section{MATERIALS AND METHODS}

This study was performed from November 2012 to May 2013, at the Intensive Rabbit Production Unit, Faculty of Agriculture, Ain Shams University, Cairo, Egypt and a Private Rabbit Farm, Kalioubia, Egypt.

\section{Experimental design:}

A total number of sixty male New Zealand White (NZW) rabbits, two months old, with mean body weight $1, \varepsilon r \pm 0.015 \mathrm{~kg}$ were used in the present study. For testing the fertility of male rabbits, 60 hybrid nonparous females aged 140 - 155 days old, with average body weight $2.90 \pm 0.23 \mathrm{~kg}$ at a private rabbitry, Kalioubia governorate, Egypt, were used in the experiment (20 females per each experimental group). Sexing of pre-pubertal males was done one week before treatment (53 days old). Males were kept in groups of 2-3 together until fighting behavior; then separated individually in galvanized wire cages in a naturally ventilated building and fed a commercial concentrate pelleted diet according to their condition recommended by NRC (1977); clean fresh water was available all the time.

Pre-pubertal male NZW rabbits were randomly divided into three groups (20 males per group). From the age of 60 days old, each male rabbit 
received $0.5 \mathrm{~mL}$ of a solution/ $\mathrm{kg}$ body weight (BW), three times weekly for 6 weeks. The solution contained: 1$)$ water for control ( $1^{\text {st }}$ group), 2) 15 $\mathrm{mg}$ propolis with $200 \mathrm{mg}$ royal jelly (RJ) suspended in $0.25 \mathrm{~mL}$ water + $0.25 \mathrm{~mL}$ bee honey ( $2^{\text {nd }}$ group), 3) $15 \mathrm{mg}$ propolis $(\mathrm{P})$ was suspended in 0.5 $\mathrm{mL}$ water $\left(3^{\text {rd }}\right.$ group).

\section{Techniques and Procedure:}

1- Live body weight: All the experimental animals were weighed weekly from the age of 60 days up to 179 days.

2- Sexual behavior: For experimental rabbit males, age at descending of testes into scrotum, age at the beginning of fighting, age at separation of penis from sheath, and age at the first ejaculation were recorded as described by Berger et al. (1982 a and b) and El-Sherbiny (1994).

3- Anatomical measurements and histological parameters: At ages of $60,90,120$ and 150 days old, 3 males from each group were sacrificed for anatomical and histological measurements. Immediately after sacrificing of rabbits, dissection of male genitalia was performed. Weights of the two testes and epididymis were recorded. Testicular index (length $\times$ depth $\times$ width) was calculated in $\mathrm{cm}^{3}$. Values obtained were calculated as mean of left and right testis and epididymis measurements. After dissection of male genitalia, the left testis and the left epididymis from each sacrificed animal were embedded in formalin $(10 \% \mathrm{v} / \mathrm{v})$, which was then replaced after $24 \mathrm{~h}$ by $70 \%$ ethanol till time of making paraffin blocks and staining with eosin / haematoxilin mixture as described by McManus and Mowry (1960). Age of appearance of spermatozoa in seminiferous tubules of testis and in epididymal ducts was recorded.

4- Blood collection and plasma Biochemical analysis: Blood samples were collected with hepariniezed tubes after sacrificing rabbits on ages of $60,90,120$ and 150 days old. Blood plasma were separated by centrifugation of blood samples at $700 \times \mathrm{G}$ for $20 \mathrm{~min}$ and stored at $20^{\circ} \mathrm{C}$ until analysis as described by Hashim et al. (2013).

Blood plasma concentrations of aspartate amino transferase (AST) and alanine amino transferase (ALT) were determined using 
colorimetric method by commercial kits according to Reitman and Frankel (1957) and Bauer (1982). Total cholesterol was determined according to Bogin and Keller (1987). Plasma testosterone concentration was measured using solid-phase enzyme immuonoassay (Elisa) kits for rabbits obtained from Chemux Bioscience, INC., San Francisco, USA. The lower limit of assay detection was $0.1 \mathrm{ng} / \mathrm{mL}$ and the upper limit was $18.0 \mathrm{ng} / \mathrm{mL}$. The intra-and inter- assay coefficients of variation (CV) were 9.6 and $6.1 \%$, respectively.

5- Semen collection and evaluation: Semen was collected artificially from each buck once weekly. Two successive ejaculates were collected; each ejaculate was kept separated for examination. The average values of both first and second ejaculates' characteristics were calculated. The parameters examined semen quality of male rabbits were: reaction time (seconds); $\mathrm{pH}$ values using $\mathrm{pH}$ comparative papers; ejaculate volume $(\mathrm{mL})$; percentage of sperm progressive motility; percentage of dead spermatozoa assessed by nigrosin-eosin staining technique; percentage of abnormal spermatozoa using $0.5 \%$ alcoholic eosin; sperm concentration $\left(\times 10^{6} / \mathrm{mL}\right)$ estimated haemocytometrically and initial fructose concentration (mg / $100 \mathrm{~mL}$ semen) using the method described by Mann (1964). Semen was evaluated as described by Zemjanis (1962), El-Sherbiny (1987) and Madhuri et al. (2012).

6-Fertility test: New Zealand White rabbit males remained ( 8 bucks from each group), aged 6 months were used for artificial insemination. For testing the fertility of rabbit bucks, 60 hybrid nonparous females, were used in the experiment (20 females per each experimental group). Semen from each experimental group was pooled together and diluted with Tris-citricglucose contained 20\% egg yolk, as described by El-Sherbiny (2013). Females chosen for insemination were thought to be sexually receptive (had red color of vulva lips). In order to induce ovulation, females were injected intramuscularly with $0.25 \mathrm{~mL}$ receptal $(\mathrm{GnRH}$ analogue, $1.05 \mu \mathrm{g}$ of busereline acetate). Then, each doe was inseminated artificially with $0.5 \mathrm{ml}$ diluted semen (containing approximately $30 \times 10^{6}$ sperms) just after $\mathrm{GnRH}$ injection. Pregnancy was detected by trans-abdominal palpation 14 days post-insemination to determine conception rate\%. Litter size was determined for each doe directly after kindling. 


\section{Statistical analysis:}

Data of body weight, body gain, semen characteristics were analyzed using repeated measurements analysis. Litter size, behavioral, anatomical and histological data were analyzed using One Way ANOVA. Whereas, for conception rate trait, Chi-square test for homogeneity of variance were performed. All statistical analysis for the different traits was realized using SAS program (SAS, 2011). Differences among experimental groups were tested by Duncan's Multiple Range test (Duncan, 1955).

Repeated measurements analysis was according to the following model:

$$
y_{i j k}=\mu+\operatorname{trt}_{i}+a_{k}(\operatorname{trt})_{i+} \text { time }_{j}+\left(\operatorname{trt} * t_{i m e}\right)_{i j}+e_{i j k}
$$

Where: $\mu$ is the overall mean, $\mathrm{y}_{\mathrm{ijk}}$ is the observation of the studied trait of $\mathrm{k}^{\text {th }}$ animal of $\mathrm{i}^{\text {th }} \operatorname{trt}$ in $\mathrm{j}^{\text {th }}$ time, $\operatorname{trt}_{\mathrm{i}}$ is the effect of $\mathrm{i}^{\text {th }} \operatorname{trt}(\mathrm{i}=1,2,3), \mathrm{an}_{\mathrm{k}}(\operatorname{trt})_{\mathrm{i}}$ is $\mathrm{k}^{\text {th }}$ animal within $\mathrm{i}^{\text {th }}$ treatment (the first error), time $\mathrm{j}_{\mathrm{j}}$ is the effect of $\mathrm{j}^{\text {th }}$ time $(j=1,2,3,4,5$ and 6 for semen quality and $j=1,2,3$ and 4 for blood plasma biochemical analysis), (trt*time) $)_{\mathrm{ij}}$ is the effect of the interaction between trt and time, $\mathrm{e}_{\mathrm{ijk}}$ is the individual error.

One way ANOVA was according to the following model:

$$
\mathrm{Y}_{\mathrm{ij}}=\mu+\mathrm{t}_{\mathrm{i}}+\mathrm{e}_{\mathrm{ij}}
$$

Where: $\mu$ is the overall mean, $Y_{\mathrm{ij}}$ is the observation of the studied trait of $j^{\text {th }}$ animal of $i^{\text {th }}$ treatment, $t_{i}$ is the fixed effect of treatment ( $i=1,2$ and 3 ), $\mathrm{e}_{\mathrm{ij}}$ is the individual error.

\section{RESULTS AND DISCUSSION}

\section{Effects on body weight and gain:}

The averages for absolute body weight $(\mathrm{kg})$ and monthly body weight gain $(\mathrm{gm})$ of control and propolis- treated NZW rabbit males from age of 2 months until 6 months are presented in Table 1. The results demonstrated that the effects of both age and treatment on both absolute body weight and body weight gain were significant $(\mathrm{P}<0.05)$. Propolis with or without royal jelly and honey treated males had higher $(\mathrm{P}<0.05)$ values of absolute body weight than control group. Also, male rabbits of $3^{\text {rd }}$ group (propolis only) showed the higher $(\mathrm{P}<0.05)$ values than the other two groups. The means of the trait are very close to values 
Table 1: Overall mean $( \pm \mathrm{SE})$ of growth parameters and behavioral phenomena of male NZW rabbits treated with propolis with or without royal jelly and honey.

\begin{tabular}{|c|c|c|c|}
\hline Items & $\begin{array}{c}\text { Control } \\
\text { group }\end{array}$ & $\begin{array}{c}2^{\text {nd }} \\
\text { group }\end{array}$ & $\begin{array}{c}3^{\text {rd }} \\
\text { group }\end{array}$ \\
\hline $\begin{array}{l}\text { Absolute body weight }(\mathrm{kg}) \\
\text { Body weight gain (gm/month) }\end{array}$ & $\begin{array}{c}2.75 \pm \\
0.008^{\mathrm{C}} \\
522.94 \pm \\
16.81^{\mathrm{B}}\end{array}$ & $\begin{array}{c}3.05 \pm \\
0.007^{\mathrm{B}} \\
666.20 \pm \\
14.81^{\mathrm{A}}\end{array}$ & $\begin{array}{c}3.20 \pm \\
0.007^{\mathrm{A}} \\
665.68 \pm \\
14.81^{\mathrm{A}}\end{array}$ \\
\hline $\begin{array}{l}\text { Mean testis weight }(\mathrm{gm}) \\
\text { Mean testis index }\left(\mathrm{cm}^{3}\right) \\
\text { Mean epididymis weight }(\mathrm{gm})\end{array}$ & $\begin{array}{l}0.79 \pm \\
0.03^{\mathrm{C}} \\
1.12 \pm \\
0.08^{\mathrm{B}} \\
0.37 \pm \\
0.02^{\mathrm{C}}\end{array}$ & $\begin{array}{l}1.07 \pm \\
0.03^{\mathrm{B}} \\
1.21 \pm \\
0.08^{\mathrm{B}} \\
0.49 \pm \\
0.02^{\mathrm{B}}\end{array}$ & $\begin{array}{l}1.38 \pm \\
0.03^{\mathrm{A}} \\
1.70 \pm \\
0.08^{\mathrm{A}} \\
0.56 \pm \\
0.02^{\mathrm{A}}\end{array}$ \\
\hline $\begin{array}{l}\text { Age of descending of testes into scrotum(days) } \\
\text { Age at separation of penis from sheath (days) } \\
\text { Age at fighting (days) } \\
\text { Age at } 1^{\text {st }} \text { ejaculation (days) }\end{array}$ & $\begin{array}{c}111.0 \pm \\
1.82^{\mathrm{A}} \\
117.9 \pm \\
1.60^{\mathrm{A}} \\
139.1 \pm \\
1.11^{\mathrm{A}} \\
139.1 \pm \\
1.15^{\mathrm{A}}\end{array}$ & $\begin{array}{c}107.3 \pm \\
1.82^{\mathrm{A}} \\
114.1 \pm \\
1.60^{\mathrm{A}} \\
121.0 \pm \\
1.11^{\mathrm{B}} \\
127.4 \pm \\
1.15^{\mathrm{B}}\end{array}$ & $\begin{array}{c}89.5 \pm \\
1.82^{\mathrm{B}} \\
93.7 \pm \\
1.60^{\mathrm{B}} \\
104.7 \pm \\
1.11^{\mathrm{C}} \\
109.9^{\mathrm{I}} \\
1.15^{\mathrm{C}}\end{array}$ \\
\hline $\begin{array}{l}\text { Age at sperm appearance in ST (days) } \\
\text { Age at sperm appearance in ductus } \\
\text { epididymis (days) }\end{array}$ & $\begin{array}{l}150.0 \pm \\
2.28^{\mathrm{A}^{*}} \\
150.0 \pm \\
2.31^{\mathrm{A}^{*}}\end{array}$ & $\begin{array}{l}143.1 \pm 2.00^{\mathrm{B}} \\
142.5 \pm 2.00^{\mathrm{B}}\end{array}$ & $\begin{array}{r}135.0 \pm \\
1.62^{\mathrm{C}} \\
135.0 \pm \\
1.63^{\mathrm{C}}\end{array}$ \\
\hline
\end{tabular}

Overall means within a row with different superscript letters differ significantly $(\mathrm{P}<0.05) . \quad \mathrm{ST}=$ Seminiferous tubules

obtained for NZW rabbits by Berger (1982a), El-Sherbiny (1994) and Lebas et al. (1997). The increasing body weight for propolis treated bucks may be due to the effect of higher concentration of testosterone (Table 3), which has anabolic effects. Testosterone possesses anabolic effects (Hafez and Hafez, 2000).

The monthly body gain decreased with increasing age, but the higher values were for $2^{\text {nd }}$ and $3^{\text {rd }}$ groups compared to control group. These findings are in agreements with those obtained by Afifi et al. 
(1989) in guinea pigs; El-Sherbiny (1994), Bonomi et al. (2001), and Elnagar et al. (2010) in rabbits.

The results of the present study were in disagreement with those obtained in rats by Yang et al. (2012) who found that royal jelly did not impart a significant effect on the body weight of the male rats. The onset of puberty is more closely related to body weight than to age (Hafez and Hafez, 2000).

\section{Effects on epididymis weight; testis weight and index:}

Mean weight of right and left testes and epididymis and testis index are presented in Table 1. Data of the present study showed that both age and treatment affected significantly $(\mathrm{P}<0.05)$ all the three anatomical parameters studied. Propolis treated- males gave always higher $(\mathrm{P}<0.05)$ values than control. Also, males of the $3^{\text {rd }}$ group had the highest $(\mathrm{P}<0.05)$ values than the other two groups. El-Sherbiny (1994) showed that pre-pubertal male NZW rabbits treated with GnRH analogue had higher testis and epididymis weight and higher testis index.

Generally, after birth the testes develop less quickly than the rest of the body (Lebas et al., 1997). From the age of five weeks they begin to grow very rapidly. The increased testis and epididymis weight for propolis treated males may be due to the higher concentration of testosterone (Table 3). Testosterone develops spermatogenesis and possesses anabolic effects (Hafez and Hafez, 2000).

\section{Effects on behavioral phenomena:}

Results in Table 1 revealed the effects of supplementation NZW rabbit males with propolis on ages at descending of testis into scrota, separation of penis from sheath, fighting and first ejaculated sperm.

Differences between the three experimental groups were significant $(\mathrm{P}<0.05)$. Propolis treated males showed earlier ages at previous phenomena compared with control males. The $3^{\text {rd }}$ group had earliest age at all traits studied. In the male rabbits, the testes remain in communication with the abdominal cavity, where they were at birth (Lebas et al., 1997). Fighting age in the present study was later than those obtained by Skinner (1967), who observed that fighting began amongst male rabbits at 60 days of age and 'bucking' (attempts to mount) about 10 days later. The rabbit is actually able to withdraw its testes 
when frightened or fighting with other males. The testicules descend at about two months (Lebas et al., 1997). They also reported that the first manifestations of sexual behavior appear at days 60 to 70 when the rabbit makes it first attempts at riding. Testosterone develops sexual behavior (Hafez and Hafez, 2000).

\section{Effects on appearance of spermatozoa in seminiferous tubules and epididymal ducts:}

Data of age at appearance of spermatozoa in testis and epididymis are presented in Table 1. Calculated data showed that spermatozoa were present for the first time in seminiferous tubules and epididymal ducts of propolis treated - groups earlier than control group. Differences between groups were significant $(\mathrm{P}<0.05)$. Basic structure of testis (seminiferous tubules cords and interstitial tissue) remains unchanged from gonadal sex differentiation at beginning of fetal life to onset of puberty (Hafez and Hafez, 2000). Spermatogenesis begins between days 40 and 50 (Lebas et al., 1997). They reported also that testicular tubes become active at about 84 days. The first spermatozoa are present in the ejaculate at about 110 days.

Testosterone is essential for spermatogenesis from spermatogonium to spermatid (West and Taylor, 1997). At puberty, gonocytes migrate to periphery of tubules; differentiate into spermatogonia; supporting cells produce Sertoli cells. These changes occur at the elevation of pre-pubertal gonadotropins (Hafez and Hafez, 2000).

\section{Effects on reaction time and semen characteristics of male rabbits:}

The means of first and second ejaculates' characteristics are presented in Table 2. Males treated with propolis had higher sexual activity reflected on lower $(\mathrm{P}<0.05)$ reaction time $(\mathrm{RT})$ in comparison with bucks in the control group. Lower reaction time for the two propolis treated groups reflects the higher concentration of testosterone (Table 3). Both propolis treatments increased significantly $(\mathrm{P}<0.05)$ ejaculate volume, sperm progressive motility, sperm-cell concentration and seminal fructose concentration. On the other hand, both treatments decreased percentages of dead and abnormal spermatozoa. The present results indicated that the positive effect of propolis administration on libido and semen characteristics of rabbit bucks during summer are in line with the 
Table 2: Overall mean $( \pm \mathrm{SE})$ of reaction time and semen characteristics of male NZW rabbits treated with propolis with or without royal jelly and honey.

\begin{tabular}{lccc}
\hline \multicolumn{1}{c}{ Items } & $\begin{array}{c}\text { Control } \\
\text { group }\end{array}$ & $\begin{array}{c}\mathbf{2}^{\text {nd }} \\
\text { group }\end{array}$ & $\begin{array}{c}\mathbf{3}^{\text {rd }} \\
\text { group }\end{array}$ \\
\hline Reaction time (seconds) & $8.1 \pm 0.04^{\mathrm{A}}$ & $6.9 \pm 0.04^{\mathrm{B}}$ & $5.7 \pm 0.04^{\mathrm{C}}$ \\
$\mathrm{pH}$ & $6.8 \pm 0.01^{\mathrm{B}}$ & $6.9 \pm 0.01^{\mathrm{A}}$ & $6.9 \pm 0.01^{\mathrm{A}}$ \\
Ejaculate volume $(\mathrm{mL})$ & $0.23 \pm 0.02^{\mathrm{C}}$ & $0.35 \pm 0.02^{\mathrm{B}}$ & $0.51 \pm 0.02^{\mathrm{A}}$ \\
Sperm progressive motility \% & $74.7 \pm 1.1^{\mathrm{C}}$ & $86.3 \pm 0.9^{\mathrm{B}}$ & $92.0 \pm 0.9^{\mathrm{A}}$ \\
Sperm concentration / mL $\left(\times 10^{6}\right)$ & $247.6 \pm 6.76^{\mathrm{C}}$ & $276.4 \pm 4.87^{\mathrm{B}}$ & $403.5 \pm 4.87^{\mathrm{A}}$ \\
Dead sperms, \% & $17.4 \pm 0.74^{\mathrm{A}}$ & $6.0 \pm 0.74^{\mathrm{B}}$ & $3.8 \pm 0.74^{\mathrm{C}}$ \\
Abnormal sperms, \% & $12.8 \pm 0.24^{\mathrm{C}}$ & $6.8 \pm 0.24^{\mathrm{B}}$ & $4.4 \pm 0.24^{\mathrm{A}}$ \\
Seminal plasma fructose $(\mathrm{mg} / 100$ & $263.8 \pm 13.03^{\mathrm{B}}$ & $287.2 \pm 13.03^{\mathrm{B}}$ & $347.2 \pm 13.03^{\mathrm{A}}$ \\
mL) & \multicolumn{3}{|l}{} \\
\hline Overall means within a row with different superscript letters differ significantly $(\mathrm{P}<0.05)$.
\end{tabular}

findings of Elnagar (2010) and Hashim et al. (2013). The values obtained in the present study were in agreements with those reported by Lebas et al. (1997) that in rabbit, volume of ejaculated semen is about 0.3 to 0.6 $\mathrm{ml}$. and that sperm concentration is elevated at 150 days old to $500 \times 10^{6}$ spermatozoa $/ \mathrm{mL}$. Body weight of the mature male rabbit at semen collection had some influence on libido, and semen characteristics (Hafez, 1970).

The enhancement of semen quality in propolis-treated male rabbits could be associated with higher concentration of testosterone (Table 3) recorded after propolis supplementation, particularly libido of bucks, ejaculate volume and seminal plasma fructose which are testosterone dependent process (El-Sherbiny, 1994; Hafez and Hafez, 2000; Hashim et al., 2013). Hafez and Hafez (2000) also concluded that fructose synthesis by the accessory sex glands was dependent on the secretion of testosterone hormone by Leydig cells of testis. The enhancement observed in sperm motility is consistent with the findings of Karacal and Aral (2008), who reported higher sperm motility when male mice were treated with RJ.

The significant increase in sperm-cell concentration can be explained by the findings of Kohguchi et al. (2004), who demonstrated that golden hamster treated with RJ showed more intensive spermatogenesis than the control group. Similar observations were 
recorded by Karacal and Aral (2008), who reported higher sperm concentration when male mice were treated with RJ. In addition, propolis treatment was capable of significantly reducing abnormal and dead sperm percentages. That comes in line with the findings of Karacal and Aral (2008), who reported lower abnormal sperm concentrations when male mice were treated with RJ. Hassan (2009) concluded that royal jelly is a beneficial treatment of adult male rats, especially on sperm count and the percentage of live sperms. On rabbits, Elnagar (2010) concluded that RJ administration to heat stressed male rabbits can counteract their "summer infertility". Also, Hashim et al. (2013) observed that inclusion of propolis in male rabbits' diets during the hot season could be used effectively to mitigate negative impacts of elevated temperature on semen quality.

In the present study, two successive ejaculates were collected separately and evaluated individually, then the mean of the two ejaculates were recorded. Lebas et al. (1997) reported that in two successive ejaculates, the first acts as a preparation for the second, which is less voluminous but more concentrated. Two ejaculates collected once a week (in a period of at least $15 \mathrm{~min}$ ) give good semen production results (ElSherbiny, 1987; Bencheikh, 1995 and Moce et al., 2000).

\section{Effects on plasma biochemical parameters and testosterone concentration:}

Data in Table 3, showed that supplementation of propolis $\left(2^{\text {nd }}\right.$ and $3^{\text {rd }}$ groups) increased significantly $(\mathrm{P}<0.05)$ plasma testosterone concentration compared to that recorded in the control group. On the other hand, blood plasma concentrations of cholesterol, AST and ALT decreased significantly $(\mathrm{P}<0.05)$ in propolis groups compared to control group.

The previous results are partly in agreements with the findings of Elnagar (2010) and Hashim et al. (2013). The second treatment (Propolis + royal jelly + honey) reduced plasma cholesterol concentration of male rabbit supporting the findings of XinNan et al. (1995), who found that treating rats with experimentally induced hyperlipaemia with $700 \mathrm{mg}$ $\mathrm{RJ} / \mathrm{kg}$ reduced serum cholesterol levels.

Liver enzymes (ALT and AST) tend to rise suggesting some liver damage in mammals and birds (QingHua and Genlin, 2007; Faisal et al., 
Table 3: Overall mean $( \pm \mathrm{SE})$ of biochemical blood parameters and fertility of male NZW rabbits treated with propolis with or without royal jelly and honey.

\begin{tabular}{lccc}
\hline Items & $\begin{array}{c}\text { Control } \\
\text { group }\end{array}$ & $\begin{array}{c}\mathbf{2}^{\text {nd }} \\
\text { group }\end{array}$ & $\begin{array}{c}\mathbf{3}^{\text {rd }} \\
\text { group }\end{array}$ \\
\hline Testosterone (ng/mL) & $1.33 \pm 0.02^{\mathrm{C}}$ & $1.98 \pm 0.02^{\mathrm{A}}$ & $2.28 \pm 0.02^{\mathrm{B}}$ \\
Cholesterol (mg/dL) & $115.8 \pm 0.30^{\mathrm{A}}$ & $105.0 \pm 0.30^{\mathrm{B}}$ & $105.2 \pm 0.30^{\mathrm{B}}$ \\
AST (IU / L) & $30.7 \pm 0.21^{\mathrm{A}}$ & $26.8 \pm 0.21^{\mathrm{B}}$ & $27.2 \pm 0.21^{\mathrm{B}}$ \\
ALT (IU / L) & $15.6 \pm 0.05^{\mathrm{A}}$ & $14.0 \pm 0.05^{\mathrm{B}}$ & $13.7 \pm 0.05^{\mathrm{C}}$ \\
\hline $\begin{array}{l}\text { Conception rate, \% (20 does) } \\
\text { Litter size at birth (No. Kids/ } \\
\text { doe) }\end{array}$ & $65.0 \mathrm{NS}$ & $75.0 \mathrm{NS}$ & $85.0 \mathrm{NS}$ \\
\hline
\end{tabular}

Overall means within a row with different superscript letters differ significantly $(\mathrm{P}<0.05) \quad \mathrm{NS}=$ Non significant

2008). In the present study, both propolis treatments caused a reduction in both enzymes, revealed an improvement in liver function. These effects are in agreement with the findings of Elnagar (2010) and Hashim et al. (2013).

\section{Effects on male rabbits' fertility:}

Results in Table 3 represent the effect of propolis on conception rate, \% (CR) and litter size at birth (LS) for rabbit does inseminated artificially with male rabbit semen of the three experimental groups. Chi-square test showed that, there were no significant differences among experimental groups in CR. On the other hand, differences in LS between groups were significant $(\mathrm{P}<0.05)$. Values of both $\mathrm{CR}$ and $\mathrm{LS}$ were higher for propolis groups than control. Increased fertility of male rabbits treated with propolis with or without royal jelly and bee honey may be due to the effect of high testosterone concentration (Table 3) that improved semen quality and resulted in high conception rate and litter size. The effect of testosterone on previous parameters was in line with the findings of El-Sherbiny (1994). Moreover, honey may improve semen quality and fertility of male rabbits as reported by Sayazana et al. (2011), who suggested that Gelam honey led to increase the fertility of male rats by increasing sperm count and number of sperm with normal morphology. 
Conclusively, it can be concluded that oral administration of propolis alone or suspended with royal jelly and bee honey to male NZW rabbits could be used beneficially to improve their reproductive characteristics (earlier age of puberty, semen quality and fertility). This improvement was also mirrored on better liver function.

\section{REFERENCES}

Afifi, E.A.; M.M. Khattab; A.A. El-Berry and A.A. Abdel-Gawad (1989). Effect of royal jelly on guinea pig growth. In Proceedings of the $4^{\text {th }}$ International Conference on Apiculture in Tropical Climates, Cairo, Egypt, 6-10 November 1988. International Bee Research Association, London, UK, pp. 42-45.

Bauer, J.D. (1982). Clinical Laboratory Methods. $9^{\text {th }}$ ed. CV Mosby Co, pp. 580 - 581.

Bencheikh, N. (1995). Effet de la fréquence de collecte de la semence sur les caractéristiques du sperme. Ann. Zoot. 44, 263-279.

Berger, M.; C. Jean-Faucher; M. de Turkheim; G. Veyssière; M.R. Blanc; J.C. Poirier and C. Jean (1982a). Testosterone, luteinizing hormone ( $\mathrm{LH})$ and follicle stimulating hormone $(\mathrm{FSH})$ in plasma of rabbit from birth to adulthood. Correlation with sexual and behavioural development. Acta Endocrinol. (Copenh.). 99 (3): 459 465.

Berger, M.; C. Jean-Faucher; M. de Turkheim; G. Veyssière and C. Jean (1982b). Age-related changes in the feedback regulation of gonadotropin secretion in the immature and adult male rabbit. Acta Endocrinol. (Copenh.). 100 (1): 18 - 24.

Bogin, E. and P. Killer (1987). Application of clinical biochemistry-try to medically revealed animal models and standardization and quality control in animal biochemistry. J. Clinical Chem. And Biochem. 25: $873-878$.

Bonomi, A.; B.M. Bonomi and A. Quarantelli (2001). Royal jelly in the feeding of rabbits. Annali della Facoltà di Medicina Veterinaria, Università di Parma. 20: 115 - 132. 
Duncan, D.B. (1955). Multiple range and multiple F-test. Biometrics, 11: 1 -42 .

Elnagar, S.A. (2010). Royal jelly counteracts bucks "summer infertility". Anim. Reprod. Sci., 121: $174-180$.

Elnagar, S.A.; O.A., Elghalid and A.M. Abd-Elhady (2010). Royal jelly: can it reduce physiological strain of growing rabbits under Egyptian summer conditions? Animal, 4 (9): 1547-1552.

El-Sherbiny, A.M. (1987). Seasonal Variations in Seminal Characteristics of Rabbits. M. Sc. Thesis, Fac. Agric., Ain Shams Univ., Cairo, Egypt.

El-Sherbiny, A.M. (1994). Some Reproductive Aspects of Male Rabbits. Ph.D. Thesis, Fac. Agric., Ain Shams Univ., Cairo, Egypt.

El-Sherbiny, A.M. (2013). Effect of royal jelly in honey-induced egg yolk based extenders on motility, viability and fertilizing ability of frozen rabbit spermatozoa. Egyptian J. Rabbit Sci., 23 (2): 149 - 160.

Faisal, B.A.; S.A. Abdel-Fattah; Y.M. El-Homosany; N.M. AbdelGawad and M.F.M. Ali (2008). Immunocompetence, hepatic heat shock protein 70 and physiological responses to feed restriction and heat stress in two body weight lines of Japanese quail. International J. Poultry Sci. 7: 174-183.

Hafez, E.S.E. (1970). Rabbits. In: Hafez, E.S.E. (Ed.), Reproduction and Breeding Techniques for Laboratory Animals. Lea and Febiger, Philadelphia, PA, pp. 273-298.

Hafez, E.S.E. and B. Hafez (2000). Reproduction in farm animals. $7^{\text {th }}$ ed., Lippincott Williams \& Wilkins; Philadelphia, Baltimore, New York, London, Buenus Aires, Hong Kong, Sydney and Tokyo.

Hashim, N.M.; A. Abd El-Hady and O. Hassan (2013). Effect of vitamin $\mathrm{E}$ or propolis supplementation on semen quality, oxidative status and hemato-biochemical changes of rabbit bucks during hot season. Livestock Sci. 157 (2): 520 - 526.

Hassan, A.A. (2009). Effect of royal jelly on sexual efficiency in adult male rats. Iraqi J. Vet. Sci., 23 (II): 155 -160.

Husein, M.Q. and S.G. Haddad (2006). A new approach to enhance reproductive performance in sheep using royal jelly in comparison with equine chorionic gonadotropin. Anim. Reprod. Sci., 93: 24 32. 
Karacal, F. and F. Aral (2008). Effect of the royal jelly on sperm quality in mice. Indian Veterinary J. 85 (3): 331- 332.

Khattab, M.M.; A.A. Radwan and E.A. Afifi (1989). Physiological effects of royal jelly on female reproductive capacity in rabbits. In Proceeding of $4^{\text {th }}$ International Congress of Apic. Trop. Clim., Cairo, Egypt, 6 - 10 November 1988. IBR, London ..... J. Apic. Res., 20(4): 249 - 253.

Kohguchi, M.; S. Inoue; S. Ushio; K. Ikeda and M. Kurimoto (2004). Effect of royal jelly diet on the testicular function of hamsters. Food Sci. Tech. Res. 10: 420 - 423.

Kumazawa, S.; T. Hamasaka and T. Nakayama (2004). Antioxidant activity of propolis of various geographic origins. Food Chem. 84: $329-339$.

Lebas, F.; P. Coundent; H. de Rochambeau and R. G. Thebault (1997). The Rabbit: husbandry, health and production (new revised version). Food and Agriculture organization of the United Nations, 1997. pp. 205.

McManus, J.F.A. and R.W. Mowry (1960). Staining Methods: Histologic and Histochemical. Hoeber Medical Division Harper \& Row, Publishers, Incorporated, New York, USA.

Madhuri, D.; V.K. Gupta; S.P. Nema; A. Patidar; M. Shivhare; N. Singh and V. Shakya (2012). Modern semen evaluation techniques in domestic animals: a review. DHR Inter. J. Biomed. life Sci., 3 (1), 62 - 83.

Mann, T. (1964). Biochemistry of semen and of the male reproductive tract, $2^{\text {nd }}$ ed. Methuen, London.

Mărghitas, L.A. (2008). Produsele Apicole Şi Principalele Lor Insuşiri Terapeutice. In: Albinele şi produsele lor. L.A. Mărghitaş, second ed. Ceres, Bucharest, pp. 280-378. Based on Pavel et al. (2011).

Moce, E.; R. Lavara; F. Lavara and J.S Vicente (2000). Effect of reproductive rhythm on seminal parameters from a rabbit line selected with high growth rate. In: Proc. 7th World Rabbit Congress. Valencia. July 2000. Vol. A: 197 - 201.

Naughton C.K.; D.R. Nelson and A.J. Thomas (2003). Development of an inexpensive artificial vagina for semen collection from rabbits. J. Androl. 24: 712 - 5. 
NRC (1977). Nutrient Requirements Of Rabbits. 2nd Review Edition. National Academy of Science. USA. CA. 30 pp.

Pavel, C.I.; L.Al.Mărghitas; O. Bobiş; D.S. Dezmirean; A. Şapcaliu; I. Radio, and M.N. Mădaş (2011). Biological activities of royal jelly. Review. Anim. Sci. Biotechnol., 44 (2): 108 - 118.

Paulino, N.; S. Abreu; Y. Uto; D. Koyama; H. Hori; V. Dirsch; A. Vollmar; A. Scremin and W. Bretz (2008). Anti-inflammatory effects of a bioavailable compound, Artepillin C, in Brazilian propolis. Eur. J. Pharmacol. 587: 296 - 301.

QingHua, L. and W. Genlin (2007). Effect of heat stress on hemorheology status and plasma inorganic ion concentration and plasma enzyme levels in dairy cows. J. Fujian Agric. and Forestry University (Natural Sci. Edition) 36: 284 - 287.

Reitman, S. and S. Frankel (1957). Colorimetric method for the determination of serum glutamic pyruvic transaminase. American J. Clinical Pathology, 28: 56 - 63.

SAS (2011). Base SAS 9.3 Procedure Guide: Statistical Procedure. Cary, NC, USA.

Syazana, N.S.; N.H. Hashida; A.M. Amjad; H.A. Durriyyah Sharifah and M.Y. Kamaruddin (2011). Effect of Gelam honey on sperm quality and testis of rats. Sains Malaysiana., 40 (11): 1243 - 1246.

Skinner, J.D. (1967). Puberty in the male rabbit. J. Reprod. Fert. 14: $151-154$.

West, J.B. Best and S. Taylor (1997). Physiology basis of medical practice. $14^{\text {th }} \mathrm{Ed}$, Williams and Wilking, London. pp: $907-933$.

XinNan, S.; L. Ruifang and H. GengShing (1995). Effect of lyophilized royal jelly on experimental hyperlipaemia and thrombosis. Zhonghua Yufang Yixue Zazhi 29: 27 - 29.

Yang, A.; M. Zhou; L. Zhang ; G. Xie H. Chen Z. Liu and W. Ma (2012). Influence of royal jelly on the reproductive function of puberty male rats. Food And Chemical Toxicology 50: 1834 -1840.

Zemjanis, R.D.V.M. (1962). Diagnostic and therapeutic techniques in animal reproduction. The Williams \& Wilkins Company, Baltimor; USA. 
EFFECT OF SOME BEE PRODUCTS ON RABBITS

Zhou, J.H.; Y. Li; J.Zhao; X.F. Xue; L.M. Wu and F. Chen (2008).

Geographical traceability of propolis by high-performance liquidchromatography fingerprints. Food Chem. 108: 749 - 59.

\section{تأثير بعض منتجات النحل على الظواهر التناسلية لذكور الأرانب النيوزيلندى الأبيض النز}

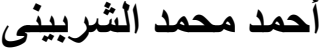

$$
\begin{aligned}
& \text { قسم الإنتاج الحيو انى ـ كلية الزر اعة - جامعة عين شمس ـ القاهرة - مصر }
\end{aligned}
$$

اجريت هذه التجربة لدر اسة تأثثر البروبوليس مع أو بدون غذاء الملكات

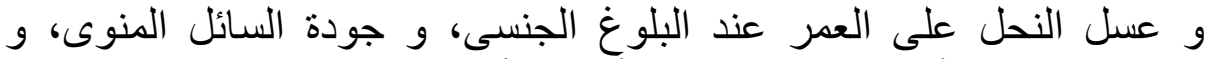

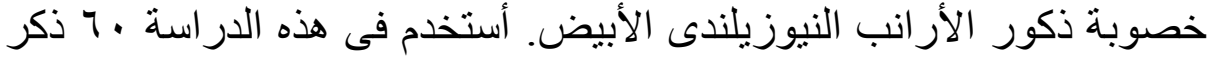

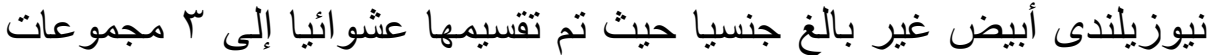

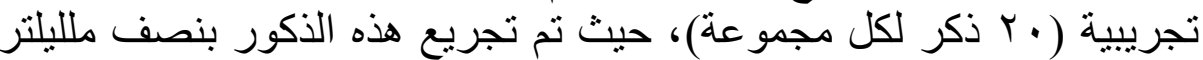

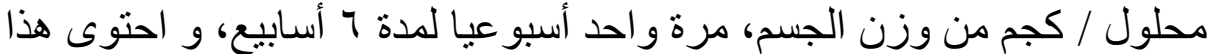

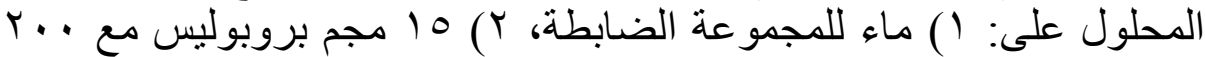

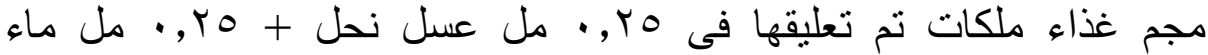

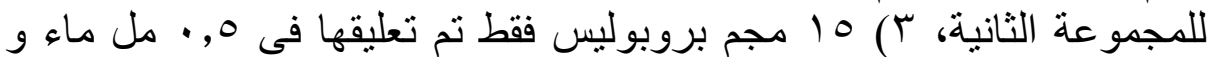

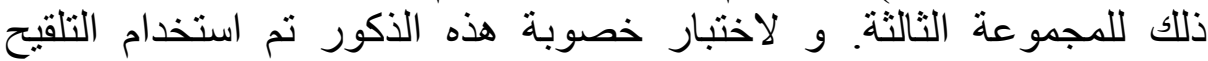

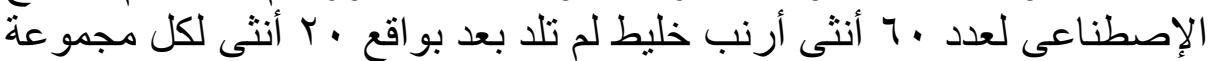

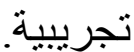
الذكور المعاملة بالبروبوليس مع أو بدون غذاء الملكات و عسل الندي النحل

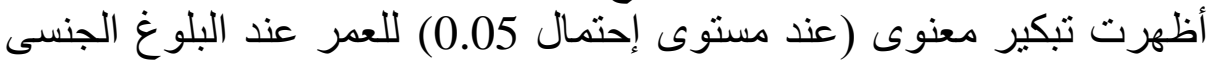

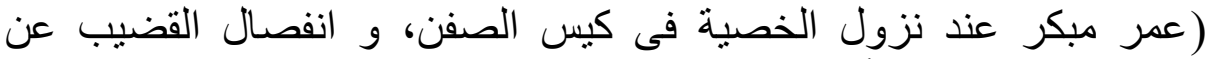

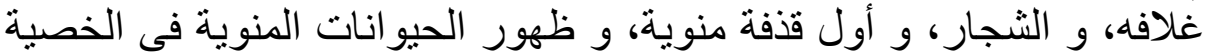

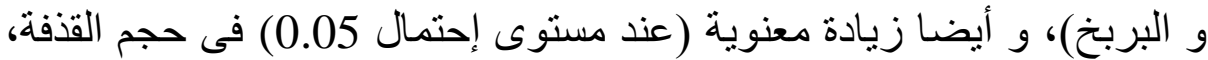

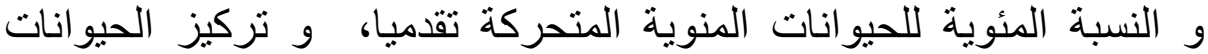

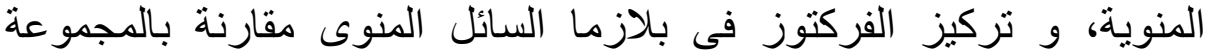




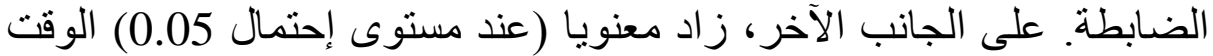

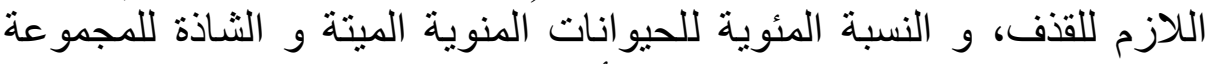

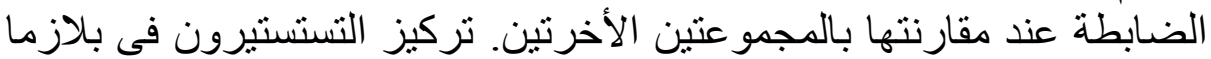

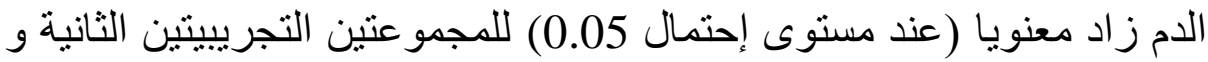

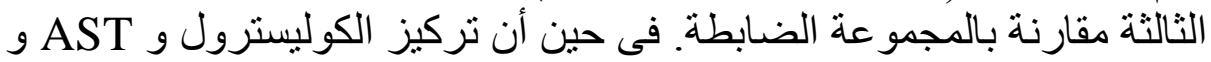
ALT

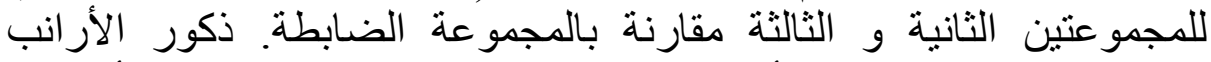

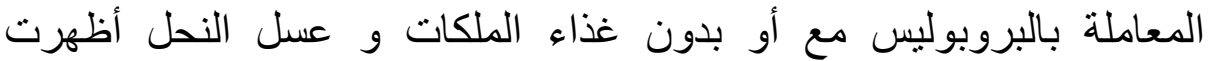

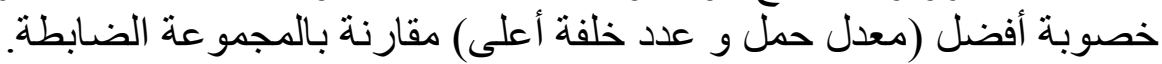

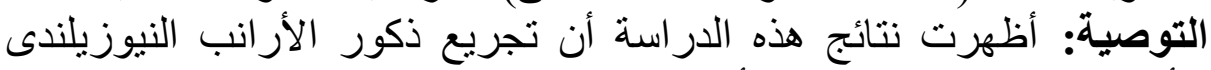

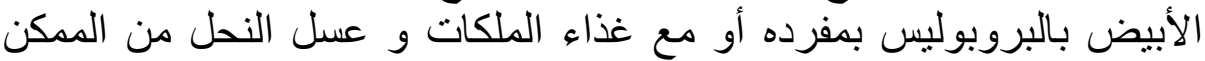

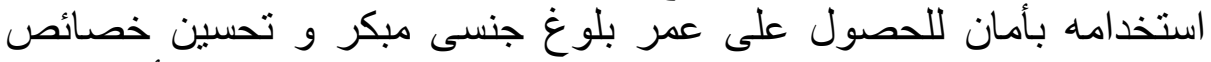

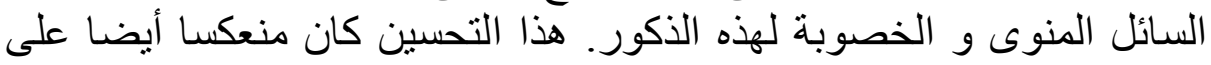
تحسن فى وظائف الكبد. 